\title{
The Mind of the Copaíba Tree: Notes on Extractivism, Animism, and Ontology from Southern Bahia
}

\author{
Jonathan DeVore ${ }^{1,2^{*}}$ \\ ${ }^{1}$ Department of the Anthropology of the Americas, University of Bonn, Bonn, Germany. ${ }^{2}$ Global South Studies Center, \\ University of Cologne, Cologne, Germany. \\ *devorejd@umich.edu
}

\begin{abstract}
This article analyzes ritualized prescriptions for harvesting oleoresin or "oil" from the copaíba tree in Brazil. These harvesting prescriptions involve increasingly complex attributions of mind to the copaíba tree itself. The copaíba tree is widespread throughout the Americas, and for centuries has been well-known for the medicinal oil that can be extracted from its trunk. In Brazil, contemporary knowledge of the copaíba tree is bound up with colonial history and what were often destructive extractivist economies. Whereas historical accounts of the copaíba tree are often limited to mechanistic descriptions for extracting oil, this article examines attributions of mind that harvesters make to the copaíba tree. These attributions can be read from procedures for extracting oil. Such procedures are concerned with moon cycles, tree marking, sexual activity, and gaze. The article shows that such prescriptions have a wide transregional and interethnic distribution, from the Amazon Basin in northern Brazil to the Atlantic Forest on Bahia's southern coast. New evidence from southern Bahia also involves prescriptions concerning speech and naming, which presuppose that the copaíba tree is sensitive to intentionality and human language. These mind attributions are inferred through pragmatic analysis of the (ontological) presuppositions that are embedded by harvesting prescriptions. The contribution concludes with reflections on the implications of this presuppositional analytic approach for debates concerned with animism and the "ontological turn."
\end{abstract}

Received April 21, 2017

OPENӘACCESS

Accepted September 5, 2017

DOI 10.14237/ebl.8.2.2017.965

Keywords Animism, Extractivism, Copaíba tree (Copaifera spp.), Atlantic forest, Brazil

Copyright (c) 2017 by the author(s); licensee Society of Ethnobiology. This is an open-access article distributed under the terms of the Creative Commons Attribution-NonCommercial 4.0 International Public License (https://creativecommons.org/licenses/by-nc/4.0), which permits non-commercial use, distribution, and reproduction in any medium, provided the original author and source are credited.

\section{Introduction}

Contemporary anthropological research on animism has focused heavily on relations between indigenous peoples and vertebrate animals, as exemplified by Viveiros de Castro's (1998:472) hunch that "the spiritualization of plants, meteorological phenomena or artefacts seems to me to be secondary or derivative in comparison with the spiritualization of animals... the extra-human prototype of the Other." SantosGranero and collaborators (2009:3) offer a sustained challenge to the "derivative" hypothesis, while Rival (2012:70) moves to enrich debates on animism by "refocusing the analytical lens on representations involving plants."

The present contribution moves along both these lines by examining attributions of mind to the copaiba tree (Copaifera spp.), which can be inferred from certain rules or prescriptions for extracting a valuable oleoresin or "oil" (óleo) from the tree's trunk. The term "mind" is employed to indicate a range of intentional and representational capacities such as sensation, emotion, perception, thought, and language. Much research on animism in South America has focused on Amerindian groups in Amazonia, while much research on copaíba oil extraction has similarly focused on the Amazon Basin. This contribution highlights comparative evidence from nonindigenous and ethnically mixed rural families living among fragments of Atlantic Forest on the southern coast of Bahia. The evidence is analyzed by unpacking the pragmatic presuppositions (Lewis 1983; Stalnaker 1999 [1974]) that are embedded by prescriptions for extracting the tree's oil. Making these presuppositions explicit helps to specify different aspects of mind that are attributed to the copaíba tree. 
This study is a result of long-term field research (38 months since 2002) with members of squatter and agrarian reform communities that were established in Bahia's cacao zone at the end of the 1990s. These communities are comprised of families with long histories working as landless plantation laborers, sharecroppers, and itinerant day laborers. Their lives have been variously shaped by legacies of colonialism and chattel slavery, and the contemporary realities of capitalism. For these families, spending much of their lives at the margins of society meant supplementing their livelihoods from the region's forests, where they could forage, hunt, and access various other means of life. These means of life included the copaíba tree from which a valuable oil can be extracted and used to cure the aches and pains of plantation labor, among other things.

The new and comparative evidence presented from southern Bahia is modest, and is not the result of a systematic study of copaiba oil extraction in the region's Atlantic Forest. The purpose of this study, then, is twofold. First, the study aims to foster comparative research on attributions of mindedness to copaíba trees and other plants in interethnic and transregional contexts. Second, the study aims to advance a pragmatic (presuppositional) analytic approach that helps to move beyond rough-hewn terms common in literature on animism-such as "subjectivity" or "personhood"-without restoring problematic notions of a shared, stable, and coherent "culture" as "ontology" (Mannheim 2016).

\section{The Copaíba Tree and its Oleoresin}

The copaíba tree is widely known to produce an oleoresin that can be used for medicinal and various other purposes (Dwyer 1951; Veiga Júnior and Pinto 2002). In the contexts of Brazilian ethnographic research and historical travel writing, the oleoresin is typically called an "oil" (óleo) and will be referred as such in this contribution. ${ }^{1}$

The copaíba tree is found throughout the Americas, where its oil has been used in ethnomedicinal and ritual practices of diverse human populations (e.g., Cohen 1984; Maretto 2013)—possibly for thousands of years (see Scheel-Ybert et al. 2013). Grandtner and Chevrette (2014:156-158) count some 37 species of copaíba across both American continents, many of which occur throughout Brazil. Orthography for copaíba in historical documents is widely varied, including capaiba, capivi, copahiba, copahu, copahyba, copaïba, copaïva, copaüba,

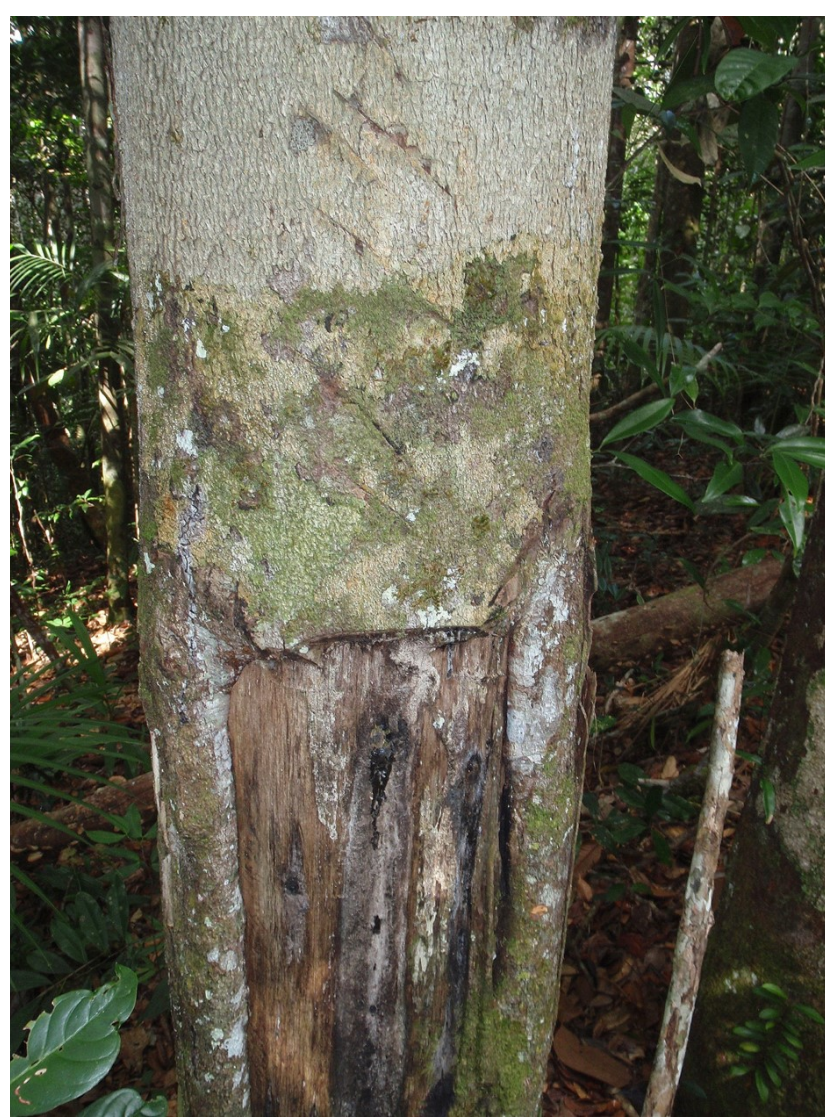

Figure 1 Copaíba tree with extraction panel near Ituberá, Bahia, Brazil, 2009. This particular tree appears to have been subject to a mix of more radical and conservative extraction methods. Photo by author.

cupahiba, cupahyba, cupahybu, and cupauba. Claude Lévi-Strauss (1952:261) includes the following: “'copayba,' 'cabima,' 'curucay,' 'curaki,' 'purukai,' 'mawna,' 'mararen,' and 'maran."' Veiga Júnior and Pinto (2002:275-276) offer several other variations, and suggest that "copaíba" comes from an indigenous Tupi term for "tree deposit" (сирa-yba). In Brazil, the copaíba tree is commonly referred to as "oil wood" (pau de óleo, pau d'óleo, pau óleo), which similarly suggests that the tree is largely viewed as a host and locus of extraction (see Figure 1).

Contemporary knowledge of the copaíba tree is entangled with Brazil's colonial history, where for centuries the tree's oil has been sought after as one of the manifold drogas do sertão, or plant products that were extracted from Brazil's diverse biomes for export to Europe (Cleary 2001:83-85; Dean 1995:130; Roller 2010:460). Historically, copaíba oil has been used as a "vehicle for paints, as a digestive, salve, antitoxin, and presumed cure for gonorrhea and elephantia- 


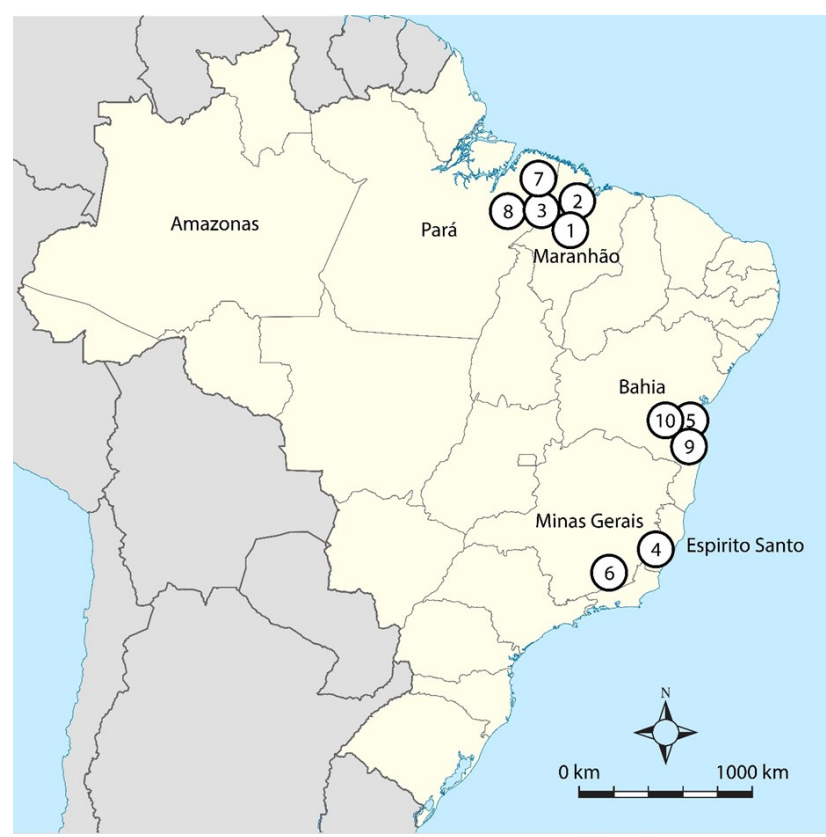

Figure 2 Distribution of cited references to copaíba oil extraction. This map was created by the author using Adobe Illustrator and compiled from a base image of Brazil available under a Creative Commons AttributionShare Alike 3.0 Unported license. Accessed on March 25, 2017.

sis" (Dean 1995:130), or as an ant repellent (e.g., Bates 1863:96). Copaíba continues to be an object of medical research for its potential antibiotic, antiinflammatory, antirheumatic, and antitumor properties (Plowden 2004; Veiga Júnior and Pinto 2002). Recent research examines larvicidal activity of copaíba against the Aedes aegypti mosquito, responsible for transmission of dengue fever, yellow fever, and the Zika virus (Mendonça et al. 2005), while other studies focus on the oil's potential use in treating cutaneous lesions caused by leishmaniasis (Oliveira dos Santos et al. 2011). Copaíba oil has also been identified as a potential biofuel, which has stimulated studies on factors affecting oil productivity (Newton et al. 2011), optimal harvest cycles (Klauberg et al. 2014), and sustainable harvesting methods (Medeiros and Vieira 2008).

\section{Copaíba Extractivist Economies in Brazil}

In different northern Brazilian states, trade in copaíba oil fostered extractivist economies that were often powered by debt-burdened labor (e.g., see Bates 1863:208-209). In the early 1860s, during his travels on the Grajaú River in the northern state Maranhão, the English explorer James W. Wells (see Figure 2, marker 1) describes an encounter with a "Capitão Dias" who was the "director, or superintendent" of an entourage of "his nude Itambeira Indians." Captain Dias, Wells (1886:283-284) recounts, was "appointed by the Government to 'catechise' them, i.e., to take charge of them, and get them to work; the results are supposed to be entirely given to the use of the tribe, but I am told the capitão has a good business, for the labours of some 200 Indians engaged in collecting balsam of copaiba, sarsaparilla, Sapucaia nuts...."

Charles Wagley and Eduardo Galvão (1948), and subsequently Mércio Pereira Gomes (1977), describe the complex extractivist economy that became central to Tenetehara social life in Maranhão (see Figure 2, marker 2). Gomes (1977:196-239) provides a comprehensive account of copaíba oil trade in this region through the 1970s, including the involvement of a local agent with the Indian Protection Service (or SPI, Serviço de Proteção aos Índios²). Gomes (1977:231232) states that,

Beginning in 1952 or earlier, the main patron to the Indians of that area... was the Grajau [Indian Protection Service] agent. He dealt both directly and indirectly with his clients. $\mathrm{He}$ travelled extensively to Indian villages where he would arrange transactions and exhort the Indians to watch 'his' cumaru trees, 'his' copaiba trees, 'his' ocelot skins, and the like. The agent also had three or four intermediaries who were SPI functionaries in three strategic villages.

In regions where coercive economic forces were at play, oil extraction may have intensified the destruction of copaíba trees through the use of radical harvesting measures, which could range from employing an ax to cut a large hole in the trunk to cutting the tree down altogether. ${ }^{3}$ Already by 1872, Gustavo Dodt wrote that oil extraction on the Gurupí river (see Figure 2, marker 3), which forms much of the border between Pará and Maranhão, has “[u] nfortunately...proceeded with true vandalism about it, such that [the tree] is already largely exterminated in many places, and what remains will not escape being destroyed in a few years" (Dodt 1939[1872]:161, author's translation). Dodt (1939[1872]:161, author's translation) describes the extraction process:

The oil is found in the heart of the tree, so it is opened with a chop from an ax that penetrates there, and that on average is $0.3 \mathrm{~m}$ 
high and about $0.4 \mathrm{~m}$ in width. The tree cannot withstand such a wound, dies, falls and rots. How many secular copaubeiras have I not seen in those woods rotting on the ground!

While the Amazon basin around Maranhão and Pará appears as a primary site for extractivist copaíba oil economies, Brazil's coastal Atlantic Forest also figures into some historical texts. In 1820, the German prince Maximilian of Wied-Neuwied (see Figure 2, marker 4) described a "republic of blacks" that was formed by slaves who took control of two plantations near the contemporary coastal town of Guarapari, Espírito Santo. Of the mixed subsistence and trade economy that was eventually established by the revolting slaves, Wied-Neuwied (1820:154; cf. Burton 1869:84) wrote:

These negroes chiefly employ themselves in collecting some of the principal productions of these forests, such as the odoriferous Peruvian, and copaiva, and another kind of balsam. The latter proceeds from a lofty tree, the Pao de Oleo. An incision is made in it, and when the sap flows the wound is filled with cotton, which imbibes the resinous matter: it is a common notion that the incision must be made at the full of the moon, and the oil taken away in the wane. The negroes, or Indians, who collect this production, bring it for sale in small wild cocoa-nutshells, the opening of which at the top they close with wax.

In 1823, on Bahia's southern coast near a small town called Marahú (see Figure 2, marker 5), Baltazar da Silva Lisboa (1823:154, author's translation) reported on the "existence of some monstrous oil woods of 140 and greater palms [palmos $\left.{ }^{4}\right]$ in length [ 30.8 meters] by 16 and 20 round [3.52 to 4.4 meters], ruined on the interior for the extraction of oil that the natives [naturaes] will sell in the pharmacies [boticas] in town."

According to a 1901 report compiled by the Bureau of the American Republics (Bureau 1901:142), the state of Bahia exported the following numbers of barrels of "copaíba oil" between 1897 and 1889:

1897: 29 barrels to the United States and 182 to Germany

1898: 14 barrels to the United States, 10 to "England and colonies", and 573 to Germany
1899 (Jan.-June): 22 barrels to the United States and 42 to Germany

By comparison, in 1889 the state of Amazonas exported 11,061 kilograms of copaíba oil (Bureau 1901:70). Although the weight of the barrels exported from Bahia is unclear, even a modest weight of 25 kilograms would put Bahian exports on par with those of Amazonas at the end of the nineteenth century.

Historical knowledge of the copaíba tree, as represented in colonial and expeditionary literature, began at the point of the oil's sale and extended to the practical uses to which it could be put. Much like the oil itself, indigenous and other local knowledge of the tree was itself viewed as an object of extraction. For those seeking to procure copaiba oil and other forest products, as Dean (1995:130) notes, "[t]he difficulty remained of drawing from tribal peoples and frontier settlers their knowledge of the resources offered by the forest." The wider cultural situation of these forest products, and the processes for extracting them from the plants that harbor them, remained comparatively veiled. Perhaps for this reason, descriptions of processes for extracting copaíba oil are often limited to mechanical methods, incisions, penetrations. For example, Alexander Caldcleugh (1825:210; see Figure 2, marker 6), an English colonial observer, noted that "in order to obtain the gum, the inhabitants puncture the bark, and affix a gourd to the place: in three or four weeks it is removed quite full."

\section{Prescriptions for Extraction in northern Brazil}

Recent ethnobotanical research suggests that some methods of extraction may involve more than a mechanistic vision of the coparba tree, involving different aspects of the tree's responsiveness and even attributions of mind. Plowden (2001, 2003, 2004; Leite et al. 2001; Shanley et al. 1998) describes several "ways a harvester should approach a [copaíba] tree" (Plowden 2003:491; see Figure 2, marker 7) to harvest the oil. The procedures and proscriptions attend to problems that may be roughly characterized as moon cycles, tree marking, sexual activity, and gaze.

\section{Moon cycles}

As Wied-Neuwied conveyed above, Plowden suggests that "[w]ould-be collectors are encouraged to harvest during the full moon..." (Plowden 2004:732 citing Leite et al. 2001).

Marking

Plowden reports that harvesters aim to "drill on the 
side of the tree where the sun rises, leans the most, or has the largest branch" (Plowden 2004:732 citing Leite et al. 2001).

\section{Sexual Activity}

Plowden relates that a "man is warned to avoid sexual relations with his wife for a few days before seeking copaíba or have a menstruating or pregnant woman present while attempting harvest" (Plowden 2004:732 citing Leite et al. 2001; cf. Plowden 2001:22-23 citing Shanley et al. 1998). One implication here is that oil extraction is a gendered activity carried out by men. Shanley and Rosa (2004:153; see Figure 2, marker 8), however, report on an interview with a woman who was involved in copaíba extraction in the 1960s, who similarly suggested that "pregnant women must never extract oil." This may be related to abortifacient properties of copaíba oil: "One woman who had five children reported that she had prevented pregnancy during her childbearing years by ingesting 1-2 drops of copaíba oil daily" (Shanley and Rosa 2004:153).

\section{Gaze}

Plowden relates that "Amazon forest people often say looking up into the canopy before attempting to harvest a tree causes the liquid to get sucked to the top" (Plowden 2004:732 citing Leite et al. 2001; cf. Plowden 2001:22 citing Shanley et al. 1998). Shanley and Rosa (2004:135) describe copaiba extraction among caboclos, or "rural peasant farmers of mixed indigenous, European and African descent," on the Capim River region just south of Belém, Pará. They report a similar rule "that extractors may not look up at the crown of the tree or the oil will disappear into the branches" (Shanley and Rosa 2004:153). ${ }^{5}$ Veiga Júnior and Pinto relate similar methods for oil procurement among contemporary silviculturists, and write that "the [copaíba] tree ought to not be looked at directly (toward the canopy), under penalty of the tree drying and the oil going back into the ground" (Veiga Júnior and Pinto 2002:275, author's translation) rather than into the canopy.

\section{Prescriptions for Extraction in southern Bahia}

Over the course of research with landless squattersturned-smallholding farmers in Bahia's coastal Atlantic Forest-more than 1,000 kilometers from the states of Amazonas, Maranhão, and Pará-I have recorded similar procedures and prescriptions for oil harvesters' approach to the copaíba tree. Moon cycles were a recurrent theme for extracting copaíba oil and other liquids, generally.

\section{Moon cycles}

Numerous people reported that "you can take tree oil on the full moon" (pode tirar óleos das árvores acima da [lua] cheia); that the full moon is the best time to "collect liquids, oil, bee's honey" (colher líquido, óleo, mel de abelha); that the full moon "yields well, there's more [to extract]" (rendoso, tem mais).

On separate occasions, two unrelated and unacquainted men named Jamie and Damião provided more detailed and nearly identical accounts of procedures for extracting copaíba oil. Jaime grew up on a small cacao farm near the municipality of Ilhéus (see Figure 2, marker 9) and variously identifies as moreno and "black" (negro). Damião spent his early childhood on his family's small cacao farm near the municipality of Nova Ibiá (see Figure 2, marker 10) in the northwestern part of Bahia's cacao zone, and variously identifies as moreno and "white" (branco), while often describing his mother as "Indian" (india). Both men described what Damião characterized as "law[s] of nature" (lei da natureza) for extracting copaíba oil.

\section{Marking}

To begin, you must identify what Jaime called the "master branch" (galho mestre), which is the largest and lowest branch on the tree. After identifying this branch, Damião explained that you must "mark the place" (marcar o lugar) on the trunk just below the branch. This is the spot where the tree will be tapped on a subsequent day, before and during which the following procedures must be observed:

\section{Moon and Day Cycles}

Damião explained that you must harvest "on the full moon" (na lua cheia; acima da cheia) and extract the oil "early in the morning" (de manbã cedo).

\section{Sexual Activity}

Jaime suggested that you cannot have sexual "relations" (relaçoes) the night before harvesting copaíba oil. Damião explained that you "can't make love" (não pode namorar) and "can't have sexual relations before going" (não pode ter relação sexual antes de ir). Damião further specified that you must wait "three days without sex" (tres dias sem namorar), and that "the man has to be purified to take the oil" ( $O$ homem tem que tá purificado pra tomar o óleo).

Gaze

Both agreed that on the day when you return to tap the tree, you must approach with your head down. 
Damião elaborated: "if you look up [at the tree], [the oil] won't come out" (se você olhar para cima, não sai).

\section{Speech}

Both Jaime and Damião agreed that you cannot talk before and during oil extraction. As an example of proscribed speech, Jaime offered the following declarative utterance: "Look, here comes the oill" (Olha, vem o óleo!). Damião explained that you should depart early in the morning "without talking with anyone" (sem falar com ninguém), elaborating that "[you can]not even say you're going to take the oil, nor holler out" (nem [pode] falar que vai tirar o óleo, nem gritar).

\section{Naming}

Both Jaime and Damião explained, finally, that you cannot speak the name of the copaíba tree during oil harvest. Damião suggested that "[you] can't speak his name" (não pode falar o nome dele), referring to the name of the copaíba tree.

Damião concluded that if you break these rules, the tree will "dry up" (secar), and "that oil vanishes, it won't appear" (some aquele óleo, não aparece). Taken together, these extraction procedures from southern Bahia overlap substantially with those that others report from northern Brazil, suggesting transregional and interethnic diffusion of knowledge, while adding further and significant admonitions about speech and naming.

\section{A Presuppositional Analysis of Extraction Prescriptions}

What can be made of these various prescriptions and procedures for harvesting oil from the copaíba tree? Taken together, as Plowden (2004:732) suggests, they indicate the difficult, uncertain, and "problematic nature of copaíba harvest." The different classes of admonitions, moreover, afford further inferences about the relational ontologies that are presupposed by those who attempt oil extraction. Questions about moon cycles, or marking the locations and branches for extraction, may admit more or less mechanistic interpretations, as when low ocean tides produce ideal space-times within which to procure crustaceans and shellfish. Questions concerning sexual purification imply that the copaiba tree may be differentially responsive to masculine and feminine gender qualities, although this may have less to do with the tree's responsiveness to pregnant or menstruating women, than with attempts to protect or regulate human reproductive cycles, as is suggested by Shanley and Rosa (2004:153).

Questions of gaze, speech, and naming indicate further attributions about copaiba tree responsiveness that involve increasingly mind-like properties. Gaze avoidance, by keeping one's face down or by not looking up into the canopy, may be related to the avoidance of mutual perceptual awareness that a hunter (human or otherwise) might seek to avoid with prey. This reading can be motivated by comparative admonitions that some indigenous Runa in the Ecuadorian Amazon make about the establishment of gaze between jaguars and human beings: "Sleep faceup! If a jaguar comes he'll see you can look back at him and he won't bother you. If you sleep facedown he'll think you're [prey, meat]... and he'll attack" (Kohn 2013:1). In other words, the establishment of mutual perceptual awareness may undermine a potentially predatory (or extractive) relationship. More speculatively, and in a rather different direction, gaze avoidance may also convey something like a show of respect to the copaíba tree, which could be plausible in locations where intensive and destructive extractive economies did not develop. The limited available evidence makes it difficult to pursue this interpretation further.

Drawing on the linguistic concept of pragmatic presupposition, Jaime's and Damião's proscriptions concerning speech and naming can be read for tacit attributions of mind to the copaíba tree. Pragmatic presupposition is concerned with whatever information is taken for granted for any assertion to be intelligible (Lewis 1983; Stalnaker 1999[1974]; see Mannheim 2016 for a recent and pertinent exposition). Such presuppositions are compelled by pragmatic aspects of language without needing to be made fully explicit. The assertion "The King of France is bald," for example, presupposes that France has a king; not only that, but the assertion presupposes that "kingship" is a phenomenon, which is to say that presuppositions carry ontological commitments. If a presupposition is previously unknown, then an assertion brings it about conversationally (Lewis 1983:234), which is to say that ontological commitments can change and shift. None of this requires acquiescence, prior agreement, shared beliefs, or even coherent (non-contradictory) sets of beliefs. For the present analysis, attention to pragmatic presuppositions is useful for making explicit tacit assumptions about the social and causal fabric of the world. 
Proscriptions on speech ("without talking with anyone"; "holler[ing] out") can be read as attempting to avoid sounds that could startle the tree and cause the oil to recede. These proscriptions minimally presuppose that the copaíba tree is acoustically attuned. The proscription of utterances that communicate an interest or intention to extract oil ("Look, here comes the oil!"; "[you can]not even say you're going to take the oil") also suggests that some people may attribute sensitivity to the copaíba tree for intentional, directed, or purposive behavior within and near its environment. These proscriptions suggest that the copaíba tree may be sensitive to intentionality that is conveyed or represented through human language.

The proscriptions on speaking the tree's name ("[you] can't speak his name"), finally, suggest that some people may also attribute an understanding of naming and reference to the copaiba tree. This reinforces the idea that some people may attribute sensitivity for human language to the tree. Not only do human beings call the copaíba tree "copaíba," but the copaíba tree itself has some degree of awareness or understanding that human beings refer to it as "coparba," "pau óleo," or other names. This is evidenced (to Jaime and Daimão) by an inferred causal relation between uttering the tree's name-no mere acoustic sound, and not just any part of speech — and undermining the oil harvest.

Precisely what is presupposed by Jaime's and Damião's proscriptions on speech and naming is indeterminate. Questions of presuppositional indeterminacy are anticipated and accommodated by the concept of pragmatic presupposition (Lewis 1983:244). But the indeterminacy is not boundless. Stated negatively, Jaime and Damião's prescriptions exclude the possibility that the copaiba tree is not sensitive to sound-and that is already something. Stated positively, and as a matter of degree, their prescriptions presuppose that the copaiba tree is acoustically attuned-necessarily so-and that the tree may in addition be sensitive to intentional behavior and understand different aspects of human language (from phonology to proper names). Making the range of possible presuppositions explicit at this stage of investigation is crucial for further research and systematic analysis. While numerous interpretations of proscriptions on gaze, speech, and naming are clearly possible, the present analysis suggests that further research on extractive processes with copaíba trees and other plants may provide a fruitful avenue for investigating quotidian forms of mindedness that people attribute to non-human lives and organisms.

\section{Conclusion}

Although the oil is still used in southern Bahia, beliefs about copaíba oil extraction processes-like the trees themselves - are unevenly distributed, and few people today extract the oil themselves. While there is little evidence to suggest that there is or ever was widespread consensus about extraction procedures, this situation in southern Bahia may parallel the "eroding knowledge" that Shanley and Rosa (2004:153) describe in the northern state of Pará: “...few Capimenses extracted oil for use. Although demand and medical need for the oil still exists, harvest has largely discontinued. In part, this may be due to diminishing accessibility of the tree; Copaifera spp. is a preferred tree of the timber industry." Indeed, Damião suggested that many people who seek to harvest copaíba oil no longer follow the procedures that he and Jaime described, as outlined above. Instead, many people simply cut the trees down with chainsaws. Damião explained that "many people don't care about old things" (muita gente não liga pra coisa antiga), referring to the prescriptions for extraction, and he concluded: "They say it's a fable, pure liesbut what I'm saying is true" (Dizem que é uma lenda, mentira pura - mas o que eu tou dizendo é a verdade).

Are these presuppositions about the mindedness of copaiba trees expressions of a fragmenting, possibly indigenous (Amerindian) knowledge, or perhaps a bricolage of practices and ideas? Did admonitions about "name" and "speech" found in southern Bahia develop in place, or might they have traceable genealogies to notions of trees and extraction that crossed the Atlantic? These are difficult questions to answer. What seems clear is that there is no single community onto which these ideas map. What is interesting is that people from diverse backgrounds and disparate regions articulate strikingly similar (albeit not always identical) ideas about the copaíba tree's mindedness, responsiveness, and perspective.

The prescriptions for copaíba oil extraction do not involve or support claims about "radical alterity" and "incommensurable worlds" (see Vigh and Sausdal 2014 for a review), or special epistemic abilities that are found in some versions of Amazonian perspectivism (e.g., indigenous shamans who "alone are capable of assuming the point of view of such [non-human] 
beings" [Viveiros de Castro 1998:472]). While copaíba oil extraction prescriptions do presuppose and instantiate different ontological claims (in the sense of "weak ontology" [see Keane 2013]), they do not rely upon a division of ontological labor or an ontological separation of worlds. In this sense, the prescriptions are epistemically and ontologically open and available. This may help to explain their widespread distribution.

This openness and availability may be accounted for by the presuppositional analysis that was pursued above. A central point about the pragmatic account of presupposition is that presupposed ideas need not be true or false, but rather accommodated within interactional contexts that involve people with one another and with other entities in the lifeworld. It need not be the case that the copaiba tree is or is not sensitive to sound or language. It does need to be the case that people involved in copaíba oil harvesting (and conversations about how to do so) presuppose that the tree has such sensitivity and mindedness. In this view, the animation of the copaíba tree (like animism generally) is a thoroughly interactional phenomenon among copaíba trees and oil harvesters, and among harvesters who deliberate about how to harvest oil from copaiba trees. Anyone who acts upon prescriptions for copaíba oil harvest-no matter who they are, no matter if they only learned about them yesterday-ipso facto accommodates their ontological presuppositions (cf. Lewis 1983:234). In one sense, then, the harvesting prescriptions and their ontological presuppositions are open and available. ${ }^{6}$

They are also open in a second sense. Just as presuppositions do not require universal acquiescence, prior agreement, or shared belief, one set of presuppositions does not need to be consistent with other presuppositions or explicit claims of "authentic" belief. One and the same person may presuppose, accommodate, or articulate ideasontological, ethical, and otherwise-that are inconsistent within the same or across different contexts. It is easy to imagine (because so common) someone confessing something as an article of faith while acting or speaking in other ways that controvert such a confession. Jaime's or Damião's presuppositions about the copaíba tree may be consistent or inconsistent with other of their presuppositions, practices, or beliefs. Such a state of (ontological) affairs is more likely the rule than the exception-unless one posits "prelapsarian" moments in human history when life was unspoiled, stable, and coherent. It makes less sense to ask what particular "ontology," "theory," or "tradition" people live by than to ask what ontological commitments their practices instantiate and accommodate. A presuppositional analytical approach helps to keep these questions open, not because answers cannot be given, but because it is unlikely that such questions will ever find single answers.

\section{Notes}

${ }^{1}$ From a chemical standpoint, the term "oil" is a misnomer. In its unprocessed state, copaíba oleoresin is comprised of resin and an essential oil that can be separated through distillation.

${ }^{2}$ As Gomes notes (1977:5), the SPI was the predecessor institution to Brazil's National Indian Foundation (or FUNAI, Fundação Nacional do Índio).

${ }_{3}^{3}$ These radical harvesting measures contrast with more conservative methods that involve boring small holes in the trunk of the tree. Historical writers cited here variously refer to "incisions," "punctures," and "penetrations" that may refer to more or less conservative extraction methods. The success of conservative methods is not guaranteed in the way that tapping a rubber tree yields a predictable flow of latex. This may help to explain the adoption of more radical and destructive harvest methods in different contexts.

${ }^{4}$ As a measure of length, one palmo was equivalent to 22 centimeters. See Miller (2000:253-256) for notes on colonial weights, measures, and coinage.

5 Shanley and Rosa (2004:150) report similar proscriptions on gazing directly at fruits in the canopy of the uxi tree (Endopleura uchi).

${ }^{6}$ There is a further consequence that can only be mentioned but not pursued here. Claims concerning "radical alterity" or "incommensurable worlds" are not unbridgeable conditions of being, but differences that are presuppositionally accommodated and interactionally sustained.

\section{Acknowledgements}

The author would like to thank his dear brother, Eduardo García Ramírez, for generously sharing his expertise in the philosophy of language over the years as well as for the purposes of completing this article. He would also like to express thanks to Juan Javier Rivera Andía for correspondence about the evidence and its theoretical import, and to the three reviewers who offered critical readings and constructive 
suggestions for revision of the initial manuscript. Finally, the author would like to thank Zola Jesus for the song "Run Me Out," which played on repeat throughout the entire drafting of the initial manuscript.

\section{Declarations}

Permissions: Informed consent was obtained from all participants in the study. This research was reviewed and approved by the Institutional Review Board through the University of Michigan's Human Research Protection Program.

Sources of funding: Different stages of fieldwork for this contribution were funded by the National Science Foundation, Doctoral Dissertation Improvement Grant (2009); Fulbright-Hays, Doctoral Dissertation Research Abroad (2009); American Philosophical Society, Lewis and Clark Fund (2010); Rackham Graduate School, University of Michigan, International Research Award (2010); and Fulbright Institute of International Education (2003-2004).

Conflicts of Interest: None declared.

\section{References Cited}

American Academy of Pediatrics, Section on Breastfeeding. 2012. Breastfeeding and the Use of Human Milk. Pediatrics 129:e827-e841. DOI:10.1542/peds.2011-3552.

Bates, H. W. 1863. The Naturalist on the River Amazons, vol. 2. John Murray, London, United Kingdom.

Bureau of the American Republics. 1901. United States of Brazil: A Geographical Sketch, with Special Reference to Economic Conditions and Prospects of Future Development. U.S. Government Printing Office, Washington, DC.

Burton, R. F. 1869. Explorations of the Highlands of the Brazil; with a Full Account of the Gold and Diamond Mines, vol. 2. Tinsley Brothers, London, United Kingdom.

Caldcleugh, A. 1825. Travels in South America, During the Years, 1819-20-21; Containing an Account of the Present State of Brazil, Buenos Ayres, and Chile, vol. 2. John Murray, London, United Kingdom.

Cleary, D. 2001. Towards an Environmental History of the Amazon: From Prehistory to the Nineteenth. Latin American Research Review 36:64-96.

Cohen, M. 1984. The Ethnomedicine of the Garifuna (Black Caribs) of Río Tinto, Honduras. Anthropological Quarterly 57:16-27.
Dean, W. 1995. With Broadax and Firebrand: The Destruction of the Brazilian Atlantic Forest. University of California Press, Berkeley, CA.

Dodt, G. 1939[1872]. Descrição dos Rios Parnaíba e Gurupy. Companhia Editora Nacional, São Paulo.

Dwyer, J. D. 1951. The Central American, West Indian, and South American species of Copaifera (Caesalpiniaceae). Brittonia 7:143-172.

Grandtner, M. M., and J. Chevrette. 2014. Dictionary of Tree, vol. 2. South America Nomenclature, Taxonomy and Ecology. Academic Press, Amsterdam, Netherlands.

Gomes, M. P. 1977. The Ethnic Survival of the Tenetehara Indians of Maranhão, Brazil. Doctoral Dissertation, Lowland South American Program, University of Florida, Gainesville, FL.

Keane, W. 2013. Ontologies, Anthropologists, and Ethical Life. HAU: Journal of Ethnographic Theory 3:186-191.

Klauberg, C., E. Vidal, L. C. E. Rodriguez, and L. Diaz-Balteiro. 2014. Determining the Optimal Harvest Cycle for Copaíba (Copaifera spp.) Oleoresin Production. Agricultural Systems 131:116122.

Kohn, E. 2013. How Forests Think: Toward an Anthropology Beyond the Human. University of California Press, Berkeley, CA.

Leite, A., A. Alechandre, C. Rigamonte-Azevedo, C. A. Campos, and A. Oliveira. 2001. Recomendações Para o Manejo Sustentável do Óleo de Copaíba. Universidade Federal do Acre and Secretaria Executiva de Floresta e Extrativismo (SEFE), Rio Branco, Brazil.

Lévi-Strauss, C. 1952. The Use of Wild Plants in Tropical South America. Economic Botany 6:252270.

Lewis, D. 1983. Scorekeeping in a Language Game. In Philosophical Papers, vol. 1. Oxford University Press, Oxford, United Kingdom.

Lisboa, B. da Silva. 1823. Memoria Topografica e Economica da Commarca dos Ilheos. Lisbon, Portugal.

Mannheim, B. 2016. The Social Imaginary, Unspoken in Verbal Art. In The Routledge Handbook of Linguistic Anthropology, edited by N. Bonvillain, pp. 44-61. Routledge, New York, NY.

Maretto, L. C. 2013. Territorialidade na Terra Indígena Uru-Eu-Wau-Wau e Manejo da Copaíba. Master's Thesis, Departamento de Geografia, 
Fundação Universidade Federal de Rondônia, Porto Velho, Rondônia, Brazil.

Medeiros, R. da Silva, and G. Vieira. 2008. Sustainability of Extraction and Production of Copaiba (Copaifera multijuga Hayne) Oleoresin in Manaus, AM, Brazil. Forest Ecology and Management 256:282-288.

Mendonça, F. A. C. de, K. F. S. da Silva, K. K. dos Santos, K. A. L. Ribeiro Júnior, and A. E. G. Sant'Ana. 2005. Activities of Some Brazilian Plants Against Larvae of the Mosquito Aedes aegypti. Fitoterapia 76:629-636.

Miller, S. W. 2000. Fruitless Trees: Portuguese Conservation and Brazil's Colonial Timber. Stanford University Press, Stanford, CA.

Newton, P., A. R. Watkinson, and C. A. Peres. 2011. Determinants of Yield in a Non-Timber Forest Product: Copaifera Oleoresin in Amazonian Extractive Reserves. Forest Ecology and Management 261:255-264.

Oliveira dos Santos, A., M. A. Costa, T. UedaNakamura, B. P. Dias-Filho, V. F. da Veiga Júnior, M. M. de Souza Lima, and C. V. Nakamura. 2011. Leishmania amazonensis: Effects of Oral Treatment with Copaiba Oil in Mice. Experimental Parasitology 129:145-151.

Plowden, J. C. 2001. The Ecology, Management and Marketing of Non-Timber Forest Products in the Alto Rio Guamá Indigenous Researve (Eastern Brazilian Amazon). Doctoral Dissertation, Intercollege Graduate Degree Program in Ecology, The Pennsylvania State University, State College, PA.

Plowden, C. 2003. Production Ecology of Copaíba (Copaifera spp.) Oleoresin in the Eastern Brazilian Amazon. Economic Botany 57:491-501.

Plowden, C. 2004. The Ethnobotany of Copaíba (Copaifera) Oleoresin in the Amazon. Economic Botany 58:729-739.

Rival, L. 2012. Animism and the Meanings of Life: Reflections from Amazonia. In Animism in Rainforest and Tundra: Personbood, Animals, Plants and Things in Contemporary Amazonia and Siberia, edited by M. Brightman, V. E. Grotti, and O. Ulturgasheva, pp. 69-81. Berghahn Books, London, United Kingdom.
Roller, H. F. 2010. Colonial Collecting Expeditions and the Pursuit of Opportunities in the Amazonian Sertão, c. 1750-1800. The Americas 66:435-467.

Santos-Granero, F. 2009. Introduction: Amerindian Constructional Views of the World. In The Occult Life of Things: Native Amazonian Theories of Materiality and Personhood, edited by F. Santos-Granero, pp. 129. University of Arizona Press, Tucson, AZ.

Scheel-Ybert, R., M. Beauclair, and A. Buarque. 2013. The Forest People: Landscape and Firewood Use in the Araruama Region, Southeastern Brazil, During the Late Holocene. Vegetation History and Archaeobotany 23:97-111.

Shanley, P., M. Cymerys, and J. Galvão. 1998. Frutiferas da Mata na Vida Amazônica. Editora Supercores, Belém, Brazil.

Shanley, P. and N. A. Rosa. 2004. Eroding Knowledge: An Ethnobotanical Inventory in Eastern Amazonia's Logging Frontier. Economic Botany 58:135-160.

Stalnaker, R. 1999[1974]. Pragmatic Presupposition. In Context and Content. Essays on Intentionality in Speech and Thought, pp. 47-62. Oxford University Press, Oxford, United Kingdom.

Veiga Júnior, V. F. da, and A. C. Pinto. 2002. O Gênero Copaifera L. Química Nova 25:273-286.

Vigh, H. E., and D. B. Sausdal. 2014. From Essence Back to Existence: Anthropology Beyond the Ontological Turn. Anthropological Theory 14:49-73.

Viveiros de Castro, E. 1998. Cosmological Deixis and Amerindian Perspectivism. The Journal of the Royal Anthropological Institute 4:469-488.

Wagley, C., and E. Galvão. 1948. The Tenetehara. In Handbook of South American Indians, vol. 3, edited by J. H. Steward, pp. 137-148. Bureau of American Ethnology, Bulletin 143. Smithsonian Institution, Washington, DC.

Wells, J. W. 1886. Exploring and Travelling Three Thousand Miles through Brazil, vol. 2. Sampson Low, Marston, Searle, and Rivington, United Kingdom.

Wied-Neuwied, P. M. 1820. Travels in Brazil, in the Years 1815, 1816, 1817. Printed for H. Colburn, London, United Kingdom. 